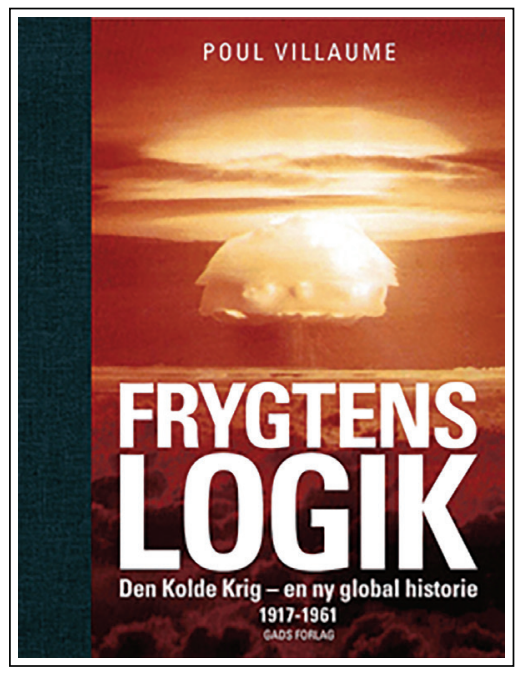

\title{
Frygtens logik. Den kolde krig: En ny global historie 1917-1961
}

\author{
Poul Villaume \\ København: Gads forlag 2020 \\ 528 sider. ISBN 9788712059639
}

Omtalt av Helge Ø. Pharo [professor emeritus i internasjonal historie, Universitetet i Oslo, helge.pharo@iakh.uio.no]

Poul Villaume har siden 1990-tallet stått frem som en av Nordens fremste kaldkrigsforskere, og han har arbeidet med både dansk utenrikspolitikk under den kalde krigen og den større konflikten. Frygtens logik er det første av to planlagte bind. Det er en bredt anlagt fremstilling, som bygger på nærlesning av et veldig litteraturtilfang så vel som et omfattende studium av primærkilder. En slik fremstilling må nødvendigvis først og fremst bygge på andres bidrag, men på en rekke viktige punkter utnytter Villaume også primærkilder, særlig amerikanske, for å belyse så vel beslutningsprosesser som aktørenes grunnleggende holdninger. Bibliografien er en gullgruve.

Som flere kaldkrigshistorikere før ham, tar Villaume på den ene siden sitt utgangspunkt i den russiske revolusjon og den universalistiske kommunistiske ideologi, og på den annen fremveksten av den amerikanske liberale internasjonalisme ved avslutningen av første verdenskrig - i president Woodrow Wilsons innpakning også en universalistisk ideologi. Villaume hevder ikke at den kalde krigen begynte i 1917, men at de to konkurrerende, universalistiske ideologiene la til rette for en omfattende konfrontasjon da USA og Sovjetunionen etter annen verdenskrig stod frem som to supermakter med globale ambisjoner. Det betyr ikke at Villaume fremstiller den kalde krigen som uavvendelig. Den var, slik han ser det, resultatet av menneskelige beslutninger og handlinger i konkrete situasjoner.

Boken er delt inn i fem store kapitler som varierer i lengde fra ca. 70 til drøyt 100 sider, og med unntak av det første kapitlet, som omhandler perioden fra 1917 til 1947, dekker de korte tidsspenn, fra to til fire år. Villaume gir de sentrale elementene $\mathrm{i}$ utviklingen av den kalde krigen en grundig behandling, særlig utviklingen av 
kjernevåpen og leveringsmidler, og dertil de overordnede strategier fra den amerikanske bruken av bomben mot Japan i krigens avslutningsfase og frem til presidentskiftet i USA i 1961. Boken slutter med at John F. Kennedy etterfulgte Dwight D. Eisenhower. Villaume understreker utvetydig USAs og den vestlige alliansens militære overlegenhet gjennom hele perioden, og finner også gjennomgående at amerikanerne var mindre innstilt på å søke gjensidig akseptable løsninger på kappløpet enn den sovjetiske motparten.

Det er spenningen i og konfliktene rundt Europa som står i sentrum for fremstillingen, i særlig grad Marshallplanen, delingen av Europa og Tyskland og det tyske problem gjennom 1950-tallet. I flere henseende er han her på linje med Marc Trachtenberg i A Constructed Peace (1999). Det gjelder også hans analyse av den vestlige militære overlegenhet. Men Villaume er også opptatt av den europeiske randsonen, Midtøsten, og av den såkalte «Tredje verden». Hans analyse omfatter de første etterkrigskrisene i Tyrkia og Iran og Truman-doktrinen, kommunistenes seier i Kina, Koreakrigen og krigene i Vietnam. Bandung-konferansen i 1955 og den alliansefrie bevegelsen har en sentral plass i kapitel 4, det har også president Gamal Nassers spill med kolonimaktene og supermaktene og Suezkrisen i 1956. I analysen av den kalde krigen utenfor Europa erVillaume på linje med Odd Arne Westad i The Global Cold War (2005) og The Cold War: A World History (2017). Han vektlegger primært amerikansk aktivisme, og for perioden frem til 1960 er det ikke urimelig. Dog etterlater han ikke noen tvil om at det var Nord-Korea som, med støtte fra Stalin og Mao, innledet Koreakrigen. Han understreker imidlertid at lokale omstendigheter kan ha spilt en større rolle enn amerikanerne den gang kunne forestille seg (s. 169). Utviklingshjelp har Villaume ikke funnet plass til i dette bindet.

Årsakene til og utviklingen av den kalde krigen har vært opphavet til omfattende debatter historikere imellom og til faglige skoledannelser. De første historikere som skrev om konflikten var i det vesentlige amerikanere, og de fant at det først og fremst var sovjetisk politikk som både la grunnlaget for konflikten og vedlikeholdt den. De er i ettertid blitt betegnet som tradisjonalister. På slutten av 1960-tallet, under inntrykket av Vietnamkrigen, overtok en gruppe yngre historikere hegemoniet i debatten. De la hovedansvaret for utbruddet av den kalde krigen på USA, og fant også at amerikansk politikk var ansvarlig for at den vedvarte. De har senere gått under betegnelsen revisjonister (om denne første debatten se Helge Pharo (red.), USA og den kalde krigen, 1972). Fra midten av 1970-tallet ble debatten særlig preget av historikere som søkte å forstå begge parters handlinger og motiver, og langt på vei unngikk en diskusjon om skyldfordeling. Det var dynamikken i utviklingen som opptok dem. Disse historikerne ble betegnet som postrevisjonister, og den norske historikeren Geir Lundestad stod sentralt i debatten. Postrevisjonistene var langt fra noen enhetlig gruppering; vi kan identifisere fløyer med klar affinitet til tradisjonalister på den ene siden og revisjonister på den annen. Etter slutten på den kalde krigen har særlig den tradisjonalistiske tendensen blitt styrket. Det skyldes ikke minst utfallet av den kalde krigen og triumfalismens gjennomslag i historiske studier. 


\section{4 | HELGE Ø. PHARO}

Villaumes tidligere arbeider må kunne betegnes som i det minste postrevisjonistiske med klart slektskap til revisjonismen. Slik må han fortsatt kategoriseres. I innledningen til Frygtens logik tar han avstand fra John Gaddis' formulering fra 2005 om at den kalde krigens historie må skrives med utgangspunkt i hvordan det gikk. Det er et klart uttrykk for triumfalistenes syn. Villaume fremholder i innledningen at han selv hele tiden i sin forskning har bestrebet seg på å understreke et åpent perspektiv. Et godt stykke på vei lever han opp til dette idealet. Det er en interaksjonsorientert og grundig kildebelagt fremstilling vi får i hende. Men perspektivet er ofte åpenbart revisjonistens. Det gjelder ikke minst i fremstillingen av Marshallplanen og delingen av Europa, hvor Villaume går svært langt i retning av å hevde at det var USAs forslag om bistand til Europa som var problemet, ikke Sovjetunionens behov for servile nabostater som skulle tjene som en sikkerhetssone. Hans gjennomgående understrekning av at Sovjetunionens handlinger, Koreakrigen unntatt, var av defensiv karakter, er om ikke urimelige så ofte utilstrekkelig diskutert i forhold til deler av den litteraturen som finnes i bibliografien.

Frygtens logik bør, som andre historiske arbeider, leses med et kritisk blikk. Tendensen i boken er som revisjonistenes - å fremheve USAs betydning og å neddempe Sovjetunionens rolle. Men jeg vil sterkt understreke at dette samtidig representerer et fremragende faglig arbeid, som er stimulerende også fordi det egger til motsigelser. 